\title{
Prevalence of adolescent idiopathic scoliosis among primary school children in Canakkale, Turkey
}

\author{
H Yilmaz ${ }^{1 *}$, C Zateri ${ }^{1}$, S Vurur ${ }^{2}$, C Bakar ${ }^{2}$ \\ From 8th International Conference on Conservative Management of Spinal Deformities and SOSORT 2011 \\ Annual Meeting \\ Barcelona, Spain. 19-21 May 2011
}

\section{Background}

Adolescent idiopathic scoliosis (AIS) is an important health problem among school children. There are a few study performed to determine prevalence of AIS. However, reported rates are many different. We aimed to determine prevalence of AIS in Canakkale.

\section{Materials and methods}

The universe of our study was chosen from primary school students. The sample size was calculated separately for provinces and districts, 1321 and 1420, respectively. We chose 12 schools totally by cluster sampling method. Presence of AIS was evaluated with scoliometre and posture analysis. Students who have skeletal deformity or major skeletal surgery history were excluded. SPSS 15.0 was used for analysis.

\section{Results}

We reached a total of 2604 students. We found47 (1.8\%) studentswith suspected AIS. All of the suspected students were invited to the hospital to assess with $x$-ray. $26(61.7 \%)$ of all students came to the hospital and we found 8 students have AIS. The data presented in this study are the preliminary results. Student evaluation is ongoing. We aim to reach all the suspected cases. Then, we will notify the prevalence of AIS among primary school children in Canakkale.

\section{Conclusions}

Idiopathic scoliosis is classified as infantile, juvenile and adolescent depending on the age at first diagnosis.

${ }^{1}$ Canakkale Onsekiz Mart University PMR Department, Canakkale, Turkey Full list of author information is available at the end of the article
Extremely rare in infancy and early childhood but has a prevalence of $1 \%$ to $2 \%$ among school children up to age 15 . We aimed to determine the frequency of AIS in the risk population of those aged 7-14 years and providing a base for large-scale studies.

\section{Author details \\ ${ }^{1}$ Canakkale Onsekiz Mart University PMR Department, Canakkale, Turkey. \\ ${ }^{2}$ Canakkale Onsekiz Mart University Canakkale, Turkey.}

Published: 27 January 2012

doi:10.1186/1748-7161-7-S1-037

Cite this article as: Yilmaz et al:: Prevalence of adolescent idiopathic scoliosis among primary school children in Canakkale, Turkey. Scoliosis 2012 7(Suppl 1):037.
Submit your next manuscript to BioMed Central and take full advantage of:

- Convenient online submission

- Thorough peer review

- No space constraints or color figure charges

- Immediate publication on acceptance

- Inclusion in PubMed, CAS, Scopus and Google Scholar

- Research which is freely available for redistribution

Submit your manuscript at www.biomedcentral.com/submit
() Biomed Central

\section{Biomed Central}

(c) 2012 Yilmaz et al; licensee BioMed Central Ltd. This is an open access article distributed under the terms of the Creative Commons Attribution License (http://creativecommons.org/licenses/by/2.0), which permits unrestricted use, distribution, and reproduction in any medium, provided the original work is properly cited. 